\title{
Molecular typing of Salmonella enterica subsp. enterica serovar Enteritidis isolates
}

\author{
BABETT LIEBISCH and S. SCHWARZ
}

Institut für Kleintierforschung der Bundesforschungsanstalt für Landwirtschaft (FAL), Dörnbergstrasse 25-27, 29223 Celle, Germany

\begin{abstract}
A collection of 31 epidemiologically unrelated Salmonella enterica subsp. enterica serovar Enteritidis ( $S$. Enteritidis) isolates obtained during a 12-year period was characterised by different molecular typing methods. Plasmid profile analysis, the detection of plasmidencoded virulence genes and ribotyping allowed little or no further differentiation amongst these isolates. Two different hybridisation patterns were observed by IS200typing of the $S$. Enteritidis isolates. However, pulsed-field gel electrophoretic separation of restriction endonuclease-digested whole-cell DNA provided a high level of discrimination amongst the $31 S$. Enteritidis isolates. This could be increased by the comparative use of the three suitable restriction endonucleases $\mathrm{Xba}$ I, SpeI and NotI. Thus, pulsedfield gel electrophoresis proved to be superior in its discriminatory value to other molecular methods such as plasmid analysis, ribotyping or IS200-typing and represents a most helpful tool for the epidemiological typing of $S$. Enteritidis isolates.
\end{abstract}

\section{Introduction}

Isolates of Salmonella enterica subsp. enterica serovar Enteritidis ( $S$. Enteritidis) are often involved in gastrointestinal diseases in man [1]. In 1992-1993, $S$. Enteritidis isolates represented more than two-thirds of all salmonellae isolated from human cases in Germany [2] and in England and Wales [3]. While other $S$. enterica serovars, such as $S$. Typhimurium, are predominant in cattle and pigs [3], strains of $S$. Enteritidis have been the most frequent isolations from poultry $[1,3]$. Among the $S$. Enteritidis isolates, those assigned to phage type (PT) 4 have been isolated predominantly from poultry, and are also the most frequent cause of salmonellosis in man [1-3]. Poultry represent a major reservoir for zoonotic $S$. Enteritidis isolates and spread occurs through eggs [4] and poultry meat [5] to man [4-6].

Different epidemiological typing methods have been established to detect chains of salmonella infections and to identify their sources. Among them, molecular techniques that analysed plasmids and chromosomal DNA fingerprinting were considered useful for typing several Salmonella serovars [7-10]. However, isolates of $S$. Enteritidis from poultry have been shown to be difficult to discriminate, even by molecular techniques $[6,11,12]$. Nevertheless, exact strain identification is

Received 23 Feb. 1995; accepted 15 June 1995.

Corresponding author: S. Schwarz. of particular importance to relate $S$. Enteritidisassociated outbreaks of salmonellosis in man to the presence of this serovar in poultry or poultry products.

In this study, $S$. Enteritidis isolates from poultry were investigated by four independent molecular typing systems. These included the detection of restriction fragment length polymorphisms (RFLP) of 16S rRNA genes as well as Salmonella-specific insertion elements in the chromosomal DNA, the characterisation of plasmids by plasmid profile analysis, restriction endonuclease digestion and demonstration of plasmidencoded virulence genes, and finally the analysis of whole-cell DNA by pulsed-field gel electrophoresis (PFGE). These techniques were compared for their discriminatory value in the molecular typing of $S$. Enteritidis.

\section{Materials and methods}

Bacterial isolates, antibiotic resistance testing and phage typing

Of the $31 S$. Enteritidis isolates used in this study, 21 were isolated from epidemiologically unrelated poultry specimens collected between 1982 and 1994 in Northern Germany. The remaining 10 isolates, obtained from unrelated cases of salmonellosis in man (five), pigs (two), cattle (two) and a dog, were included in this study for comparative purposes. Biochemical characterisation of the $S$. Enteritidis isolates followed standard techniques; serotyping was performed with 
commercially available antisera (Behring Werke, Marburg, Germany). All $S$. Enteritidis isolates were grown overnight on LB-agar plates; glycerine stock cultures were kept at $-70^{\circ} \mathrm{C}$. The isolates were checked for purity on sheep blood agar plates (Blood Agar Base, Oxoid, supplemented with sheep blood 7.5\%). Antibiotic susceptibility testing was performed by the agar diffusion method [13] with disks containing ampicillin $10 \mu \mathrm{g}$, chloramphenicol $30 \mu \mathrm{g}$, fusidic acid $10 \mu \mathrm{g}$, gentamicin $10 \mu \mathrm{g}$, kanamycin $30 \mu \mathrm{g}$, minocycline $30 \mu \mathrm{g}$, nalidixic acid $30 \mu \mathrm{g}$, neomycin $30 \mu \mathrm{g}$, nitrofurantoin $300 \mu \mathrm{g}$, penicillin G 10 I.E. and tetracycline $30 \mu \mathrm{g}$. Phage typing was performed at the Statens Veterinaere Serumlaboratorium, Copenhagen, Denmark, according to the method of Ward et al. [14] by the phage typing scheme developed at the Central Public Health Laboratory, Colindale Avenue, London.

\section{DNA preparation, agarose gel electrophoresis and restriction endonuclease analysis}

The preparation of whole-cell DNA of the $S$. Enteritidis isolates followed a Salmonella-specific modification [15] of the method of Jordens and Hall [16]. Plasmid profiles of the $S$. Enteritidis isolates were prepared according to Kado and Liu [17]. The plasmids of Escherichia coli V517 [18] as well as the $S$. Typhimurium virulence plasmid pRQ51 [19] served as standards for the determination of plasmid sizes in the $S$. Enteritidis isolates. Plasmids suitable for subsequent restriction endonuclease analyses were obtained by the method of Olsen [20]. Uncleaved plasmids as well as their restriction fragments were separated electrophoretically in agarose $0.8 \% \mathrm{w} / \mathrm{v}$ gels [21], stained with an aqueous solution of ethidium bromide (Sigma) $10 \mu \mathrm{g} / \mathrm{ml}$ and photographed under UV illumination. $S$. Enteritidis plasmids were digested for $2 \mathrm{~h}$ with $10 \mathrm{U}$ of HindIII (Boehringer Mannheim, Germany) according to the manufacturer's recommendations.

Approximately $1 \mu \mathrm{g}$ of whole-cell DNA was digested at $37^{\circ} \mathrm{C}$ for $4 \mathrm{~h}$ in the presence of $30 \mathrm{U}$ of the enzymes Sma I, PvuII or PstI [21]. The resulting DNA fragments were separated in agarose $0.8 \% \mathrm{w} / \mathrm{v}$ gels. A $1-\mathrm{kb}$ ladder and $\lambda$-DNA/HindIII fragments (both from Gibco-BRL, Paisley) served as DNA size standards.

\section{Southern blot hybridisation and preparation of gene probes}

The DNA fragments were transferred from agarose gels to nitrocellulose membranes (Hybond N, AmershamBuchler, Braunschweig, Germany) by the capillary blot procedure [21]. The 2.3-kb HindIII fragment of plasmid pBA2 [22] was used as a $16 \mathrm{~S}$ rRNA probe and the 0.6-kb $P v u$ II fragment of plasmid pIZ45 [23] served for the detection of IS200 elements. A 3.6-kb HindIII fragment of plasmid pRQ51 [19] — which comprised the virulence genes $s p v \mathrm{~B}$ and $s p v \mathrm{C}$ within the common region of virulence plasmids in S. enterica serovars Typhimurium, Enteritidis, Dublin and Choleraesuis [23-26] - served as a virulence gene probe. The non-radioactive ECL system (Amersham-Buchler) was used to label all gene probes. Hybridisation was performed overnight at $42^{\circ} \mathrm{C}$ in a shaking water bath $(80 \mathrm{rpm})$ with the hybridisation buffer included in the kit. The membranes were washed twice for $20 \mathrm{~min}$ at $42^{\circ} \mathrm{C}$ in a buffer consisting of $6 \mathrm{M}$ urea SDS $0.4 \% \mathrm{w} / \mathrm{v}$ and $0.1 \times$ SSC $(1.5 \mathrm{mM}$ sodium citrate, $15 \mathrm{mM}$ sodium chloride, $\mathrm{pH} 7.0$ ) and twice for $5 \mathrm{~min}$ at room temperature in $2 \times \mathrm{SSC}$. The detection solutions included in the ECL kit were used for the detection of hybridisation signals.

\section{Pulsed-field gel electrophoresis (PFGE)}

Whole-cell DNA for PFGE experiments was prepared as described previously $[11,27]$. DNA containing slices of the agarose plugs were digested for $4 \mathrm{~h}$ with $20 \mathrm{U}$ of $X b a \mathrm{I}$ (Boehringer), $20 \mathrm{U}$ of NotI or $20 \mathrm{U}$ of Spe I (BioLabs). The resulting DNA fragments were separated by agarose gel electrophoresis with SeaKem GTG (FMC Bio Products) $1 \% \mathrm{w} / \mathrm{v}$ in a CHEF DR II system (BioRad) at $15 \mathrm{~V} / \mathrm{cm}$ with $0.5 \times \mathrm{TBE}$ as running buffer. The pulse times for $X b a \mathrm{I}$ and SpeI digests were increased from $7 \mathrm{~s}$ to $12 \mathrm{~s}$ during the first $11 \mathrm{~h}$ and finally from $20 \mathrm{~s}$ to $40 \mathrm{~s}$ during the next $13 \mathrm{~h}$; for NotI digests, the pulse times were increased from $2 \mathrm{~s}$ to $5 \mathrm{~s}$ during the first $11 \mathrm{~h}$ and from $9 \mathrm{~s}$ to $12 \mathrm{~s}$ for further $11 \mathrm{~h}$. Polymerised phage $\lambda$ DNA (Pharmacia LKB) served as size standard. The gel was stained with ethidium bromide, (Sigma) $2 \mu \mathrm{g} / \mathrm{ml}$ for $15 \mathrm{~min}$, destained in distilled water for $15 \mathrm{~min}$ and photographed under UV illumination. To determine the possible interference of virulence plasmid bands on the PFGE fragment patterns, the DNA fragments were transferred to nitrocellulose membranes, fixed by baking and hybridised with the $s p v \mathrm{~B} / s p v \mathrm{C}$ gene probe.

\section{Calculation of the discriminatory indices for the different typing methods}

An index of discrimination $(D)$ for each typing method was calculated according to Simpson's index of diversity as described by Hunter and Gaston [28]. It is based on the probability that two unrelated strains randomly sampled from the test population will be assigned to different typing groups. This index was used to compare the different typing methods and select the most discriminatory system.

\section{Results}

Resistance testing, phage typing and plasmid analysis

None of the $31 \mathrm{~S}$. Enteritidis isolates exhibited resistance to any of the antibiotics tested. Phage typing 
Table 1. Characteristics of the $31 \mathrm{~S}$. Enteritidis isolates

\begin{tabular}{|c|c|c|c|c|c|c|c|c|}
\hline \multirow{2}{*}{$\begin{array}{l}\text { Isolate } \\
\text { (Source*) }\end{array}$} & \multirow{2}{*}{$\begin{array}{l}\text { Phage } \\
\text { type }\end{array}$} & \multirow{2}{*}{$\begin{array}{l}\text { Plasmid } \\
\text { profile } \\
(\mathrm{kb})\end{array}$} & \multirow[b]{2}{*}{ Ribotype } & \multirow{2}{*}{$\begin{array}{l}\text { IS200 } \\
\text { type }\end{array}$} & \multicolumn{3}{|c|}{ PFGE patterns } & \multirow{2}{*}{$\begin{array}{c}\text { Genomic } \\
\text { group }\end{array}$} \\
\hline & & & & & $X b a \mathrm{I}$ & SpeI & Not I & \\
\hline $1(\mathrm{P})$ & $\mathrm{RDNC} \dagger$ & 55 & 1 & 1 & 1 & 1 & 4 & I \\
\hline $2(\mathrm{P})$ & 8 & 55 & 1 & 2 & 1 & 2 & 2 & \\
\hline $3(\mathrm{P})$ & 8 & 55 & 1 & 2 & 1 & 2 & 2 & \\
\hline $4(P)$ & 8 & 55 & 1 & 2 & 1 & 2 & 2 & \\
\hline $\begin{array}{l}5(\mathrm{P}) \\
6(\mathrm{P}) \\
7(\mathrm{H}) \\
8(\mathrm{P})\end{array}$ & $\begin{array}{c}8 \\
8 \\
8 \\
\text { RDNC }\end{array}$ & $\begin{array}{l}55 \\
55 \\
55 \\
55\end{array}$ & $\begin{array}{l}1 \\
1 \\
1 \\
1\end{array}$ & $\begin{array}{l}2 \\
2 \\
2 \\
2\end{array}$ & $\begin{array}{l}1 \\
1 \\
1 \\
1\end{array}$ & $\begin{array}{l}2 \\
2 \\
2 \\
2\end{array}$ & $\begin{array}{l}2 \\
2 \\
2 \\
2\end{array}$ & II \\
\hline $9(\mathrm{P})$ & 13 & 55 & 1 & 2 & 1 & 2 & 5 & III \\
\hline $\begin{array}{l}10(\mathrm{P}) \\
11(\mathrm{P}) \\
12(\mathrm{P}) \\
13(\mathrm{P}) \\
14(\mathrm{P}) \\
15(\mathrm{P}) \\
16(\mathrm{P}) \\
17(\mathrm{D})\end{array}$ & $\begin{array}{c}4 \\
4 \\
4 \\
4 \\
4 \\
7 \\
\text { RDNC } \\
4\end{array}$ & $\begin{array}{l}55 \\
55 \\
55 \\
55 \\
55 \\
55 \\
55 \\
55\end{array}$ & $\begin{array}{l}1 \\
1 \\
1 \\
1 \\
1 \\
1 \\
1 \\
1\end{array}$ & $\begin{array}{l}1 \\
1 \\
1 \\
1 \\
1 \\
1 \\
1 \\
1\end{array}$ & $\begin{array}{l}2 \\
2 \\
2 \\
2 \\
2 \\
2 \\
2 \\
2\end{array}$ & $\begin{array}{l}3 \\
3 \\
3 \\
3 \\
3 \\
3 \\
3 \\
3\end{array}$ & $\begin{array}{l}2 \\
2 \\
2 \\
2 \\
2 \\
2 \\
2 \\
2\end{array}$ & IV \\
\hline $18(\mathrm{P})$ & RDNC & 55 & 1 & 1 & 3 & 3 & 6 & $\mathrm{~V}$ \\
\hline $\begin{array}{l}19(\mathrm{P}) \\
20(\mathrm{P}) \\
21(\mathrm{P}) \\
22(\mathrm{P}) \\
23(\mathrm{~S}) \\
24(\mathrm{H}) \\
25(\mathrm{H}) \\
26(\mathrm{C}) \\
27(\mathrm{C})\end{array}$ & $\begin{array}{l}1 \\
1 \\
1 \\
1 \\
1 \\
1 \\
1 \\
1 \\
1\end{array}$ & $\begin{array}{l}55 \\
55 \\
55 \\
55 \\
55 \\
55 \\
55 \\
55 \\
55\end{array}$ & $\begin{array}{l}1 \\
1 \\
1 \\
1 \\
1 \\
1 \\
1 \\
1 \\
1\end{array}$ & $\begin{array}{l}1 \\
1 \\
1 \\
1 \\
1 \\
1 \\
1 \\
1 \\
1\end{array}$ & $\begin{array}{l}4 \\
4 \\
4 \\
4 \\
4 \\
4 \\
4 \\
4 \\
4\end{array}$ & $\begin{array}{l}2 \\
2 \\
2 \\
2 \\
2 \\
2 \\
2 \\
2 \\
2\end{array}$ & $\begin{array}{l}1 \\
1 \\
1 \\
1 \\
1 \\
1 \\
1 \\
1 \\
1\end{array}$ & VI \\
\hline $\begin{array}{l}28(\mathrm{P}) \\
29(\mathrm{H})\end{array}$ & $\begin{array}{l}6 \\
6\end{array}$ & $\begin{array}{l}55 ; 23 \\
55 ; 23\end{array}$ & $\begin{array}{l}1 \\
1\end{array}$ & $\begin{array}{l}1 \\
1\end{array}$ & $\begin{array}{l}2 \\
2\end{array}$ & $\begin{array}{l}4 \\
4\end{array}$ & $\begin{array}{l}3 \\
3\end{array}$ & VII \\
\hline $30(\mathrm{~S})$ & 1 & $55 ; 3$ & 1 & 1 & 2 & 5 & 2 & VIII \\
\hline $31(\mathrm{H})$ & 1 & 55 & 1 & 1 & 2 & 2 & 2 & IX \\
\hline
\end{tabular}

*P, poultry; H, human; C, cattle; S, swine; D, dog.

showed that six isolates each belonged to the PTs 4 or 8,11 isolates could be assigned to PT1 and two to PT6, whereas single isolates corresponded to phage types 7 and 13, respectively. Another four $S$. Enteritidis isolates reacted with the typing phages, but their lytic pattern did not correspond to any recognised phage types; these isolates were classified as RDNC (Table 1). Phage typing resulted in a discriminatory index $(D)$ of 0.755 . Twenty-eight of the 31 isolates carried a single plasmid of $c .55 \mathrm{~kb}$, and additional plasmids of either $23 \mathrm{~kb}$ or $3 \mathrm{~kb}$ were detected in the remaining three $S$. Enteritidis isolates (Table 1). This corresponded to a discriminatory index of 0.187 for plasmid profile analysis. Hybridisation of these plasmids with a virulence gene probe identified the 55-kb plasmid in each isolate as a virulence plasmid. Restriction endonuclease analyses of these virulence plasmids revealed no differences in the fragment patterns. Moreover, hybridisation experiments demonstrated that the virulence genes were located on fragments of $3.6 \mathrm{~kb}$ in each of the 31 virulence plasmids (Fig. 1).

\section{Ribotyping}

Independently of the enzyme used for digestion of the whole-cell DNA, ribotyping with the 16S rRNA probe resulted in identical hybridisation patterns for the 31 isolates. An extended hybridisation pattern consisting of six bands was obtained by probing $P v u$ II-digested DNA with the 16S rRNA gene probe (Fig. 2); only one hybridising fragment was detected by Sma I-digested DNA. The latter observation suggested that an internal fragment of the 16S rRNA gene was obtained by digestion with SmaI to which the gene probe hybridised. The discriminatory index for ribotyping was 0 . 
a

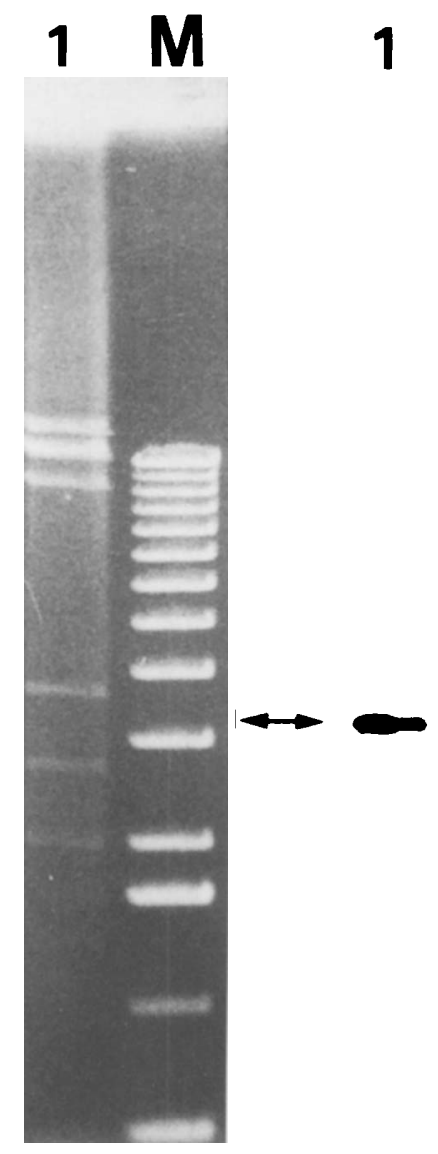

Fig. 1a, HindIII restriction patterns of the virulence plasmid found in all $31 \mathrm{~S}$. Enteritidis strains (lane 1); b, corresponding hybridisation pattern obtained with an $s p v \mathrm{~B} / s p v \mathrm{C}$ virulence gene probe (lane 1); $\mathbf{M}$, DNA length standard (1-kb ladder, Gibco-BRL). The arrows indicate the hybridising fragment of $3.6 \mathrm{~kb}$.

\section{IS200 typing}

Hybridisation experiments with an IS200-specific gene probe confirmed that all $31 \mathrm{~S}$. Enteritidis strains harboured insertion elements of this type. Two different hybridisation patterns were observed. Twenty-three $S$. Enteritidis isolates carried their IS200 copies on Pst I fragments of $4.5 \mathrm{~kb}$ and $6.7 \mathrm{~kb}$ (IS200 type 2); the remaining eight isolates showed hybridising Pst $\mathrm{I}$ fragments of $4.5 \mathrm{~kb}$ and $5.2 \mathrm{~kb}$ (IS200 type 1) (Fig. 3). Since hybridisation of the electrophoretically separated plasmids with the IS200-specific gene probe revealed no signals, all IS200 copies were considered to be located in the chromosome. IS200 typing yielded a $D$ value of 0.396 .

\section{PFGE}

PFGE analyses of restriction endonuclease-digested whole-cell DNA revealed the presence of four different fragment patterns with $X b a \mathrm{I}$ (Fig. 4a, lanes 6-9). SpeI

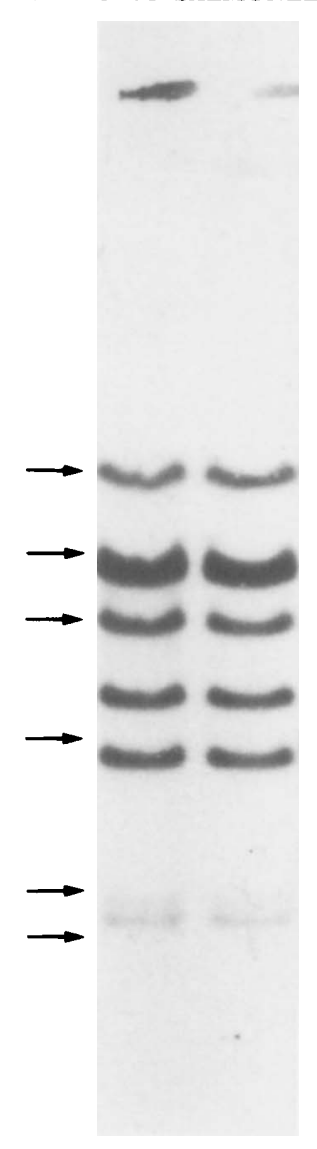

Fig. 2. Typical $P v u$ II-ribotyping pattern observed in all $31 \mathrm{~S}$. Enteritidis isolates. Arrows indicate the positions of the DNA marker fragments ( $\lambda$ DNA HindIII-digested, Gibco-BRL) as they appeared in the respective agarose gels (from the top: 23130, 9416, 6557, 4361, 2322, $2027 \mathrm{bp}$ ).

digestion resulted in another five different fragment patterns (Fig. 4a, lanes 1-5) while six fragment patterns were observed by digestion with the enzyme NotI (Fig. 4b, lanes 1-6). Whereas $X b a \mathrm{I}$ and SpeI produced fragment patterns consisting of 13-16 bands in the range $48-533 \mathrm{~kb}$, those obtained from Not I digestion resulted in 29-32 fragments of $48-339 \mathrm{~kb}$. The indices of discrimination were 0.703 for the $X b a \mathrm{I}$ patterns and 0.591 for the SpeI and Not I patterns. The comparative use of the three restriction endonucleases in PFGE analyses significantly increased the discriminatory value of this technique to $D=0.815$ as isolates that exhibited the same fragment pattern with one enzyme occasionally differed in their fragment patterns obtained with the other enzymes. Thus, nine different genomic groups could be differentiated among the $31 \mathrm{~S}$. Enteritidis isolates (Table 1) on the basis of combined PFGE analyses.

\section{Discussion}

A specific strain identification is essential for monitoring the spread of salmonellae during outbreaks of infection. Traditional epidemiological studies included biochemical and serological characteristics of the 


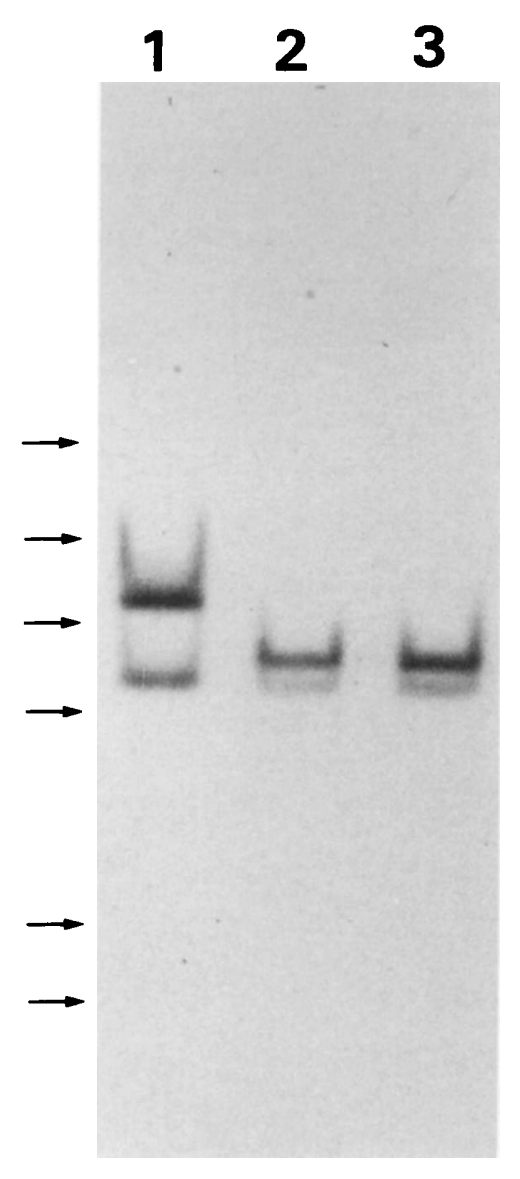

Fig. 3. IS 200 patterns obtained by hybridising Pst Idigested chromosomal DNA with a gene probe specific for the insertion element IS200. The hybridisation patterns 1 and 2 represent the IS200 types 1 and 2 as

isolates as well as their antibiotic resistance properties and, if available, their assignment to certain phage types.

Genotypic analysis of salmonellae by molecular typing methods has proved to be helpful in the characterisation of strains from different Salmonella serovars, such as $S$. Typhimurium $[6,15,27,29], S$. Enteritidis [6, 9$11,30-33], S$. Dublin [24,34], $S$. Virchow [35], $S$. Heidelberg [36], $S$. Berta [37,38], $S$. Typhi [39], $S$. Paratyphi [40] and $S$. Java [40]. The techniques included plasmid analysis, ribotyping, IS200 typing and PFGE analysis. Although these methods are universally applicable, they have different discriminatory values for isolates of the different Salmonella serovars.

Although plasmid analyses were not included, previous studies of $S$. Enteritidis that included the type strains of the different phage types, as well as small numbers of additional strains of selected phage types, have shown that these molecular typing methods were useful for the determination of evolutionary lines among $S$. Enteritidis strains from different phage types $[11,30]$.
However, these studies also revealed that IS200 typing did not allow discrimination between strains of the same phage type or among strains from different PTs, such as $1,4,6$ or $7[11,30]$. Similar observations were made for the discriminatory value of ribotyping $[11,41]$. Another study of field isolates of $S$. Enteritidis showed that both methods - ribotyping and IS200 typing - failed to discriminate between 14 $S$. Enteritidis isolates [6]. PFGE analyses appeared to have the best discriminatory value of all molecular typing methods [11]. By using PFGE analysis with Not I-digested whole-cell DNA, $S$. Enteritidis isolates of the same phage type as shown for those belonging to PTs 1,6 or 7 could be differentiated, whereas isolates of PT4 remained indistinguishable [11,33]. However, Powell et al. subdivided $39 \mathrm{~S}$. Enteritidis PT4 isolates obtained during a 25-year period into nine $X b a$ I-PFGE patterns [12].

Based on these findings four independent molecular techniques were used to study 31 unrelated $S$. Enteritidis isolates. As previously demonstrated by others [6], ribotyping with $S m a \mathrm{I}$ and $P v u$ II failed to discriminate between the different $S$. Enteritidis isolates. Although SmaI had been reported to be helpful for ribotyping Salmonella serovars Enteritidis [41] and Berta [38] and PvuII had been used successfully for serovars Typhimurium $[15,29]$, Paratyphi [40] and Java [40], neither enzyme revealed differences between the $S$. Enteritidis isolates used in this study.

Furthermore, plasmid analyses did not demonstrate striking differences between the $S$. Enteritidis isolates. Most carried a single plasmid of $55 \mathrm{~kb}$ that had been reported to be specific for serovar Enteritidis [42], whereas additional smaller plasmids could be detected in three isolates. This observation is in good agreement with other studies on plasmid profiles in $S$. Enteritidis $[42,43]$. The $55-\mathrm{kb}$ plasmid of each isolate was identified as a virulence plasmid by hybridisation with a specific gene probe. Moreover, all these virulence plasmids proved to be indistinguishable by their fragment patterns obtained after HindIII digestion. This enzyme had been used successfully to detect structural differences among virulence plasmids in $S$. Typhimurium [15] and $S$. Enteritidis [43]. In each case the virulence gene probe hybridised to a $3.6-\mathrm{kb}$ HindIII fragment that had been reported to be an internal area of the common virulence gene region in plasmids of serovars Typhimurium, Enteritidis, Dublin and Choleraesuis [25]. Thus, plasmid analyses did not provide substantial strain-specific information suitable for tracing strains of $S$. Enteritidis.

The detection of IS200 copies has proved to be a useful tool for the epidemiological typing of many different Salmonella serovars. This method was particularly helpful for serovars that usually harboured a large number of IS200 copies such as Typhimurium 

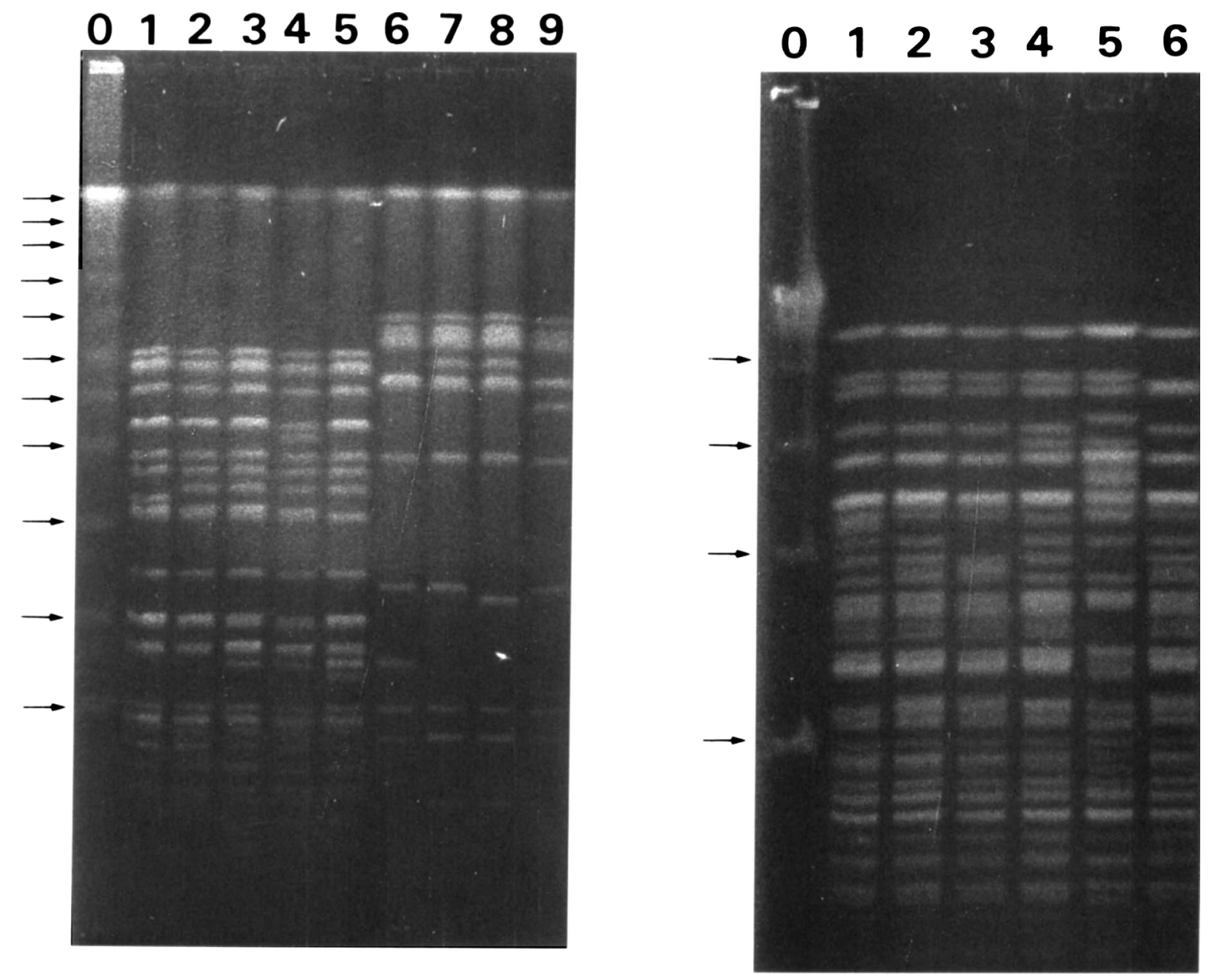

Fig. 4. Agarose gel electrophorogram of the different PFGE-patterns of $S$. Enteritidis isolates obtained with: a, the restriction endonucleases SpeI- (lanes 1-5) as well as XbaI- (6-9) or b, NotI (lanes 1-6); 0, DNA size standard (polymerised phage $\lambda$ DNA, Pharmacia LKB); arrows indicate the positions of the marker DNA fragments starting from the bottom at $48.5 \mathrm{~kb}$.

[15, 29], Typhi [39], Paratyphi [40], Java [40] and Heidelberg [36]. In other serovars, such as Berta $[37,38]$ and Enteritidis [30-32], its use for epidemiological typing was limited due to the low number of IS200 copies in these strains. Nevertheless, IS200 typing revealed the presence of two distinct and stable hybridisation patterns among the strains investigated in this study. By using Pst I for the digestion of wholecell DNA IS200 types were obtained that corresponded very closely to the types 1 and 2 , as reported previously $[11,32]$. The data on IS200 typing strongly support the observation that certain $S$. Enteritidis phage types are identified by their IS200 hybridisation patterns. Thus, all isolates of PTs 8 and 13 corresponded to IS200 type 2 whereas isolates of PTs 1, 4, 6 and 7 exhibited IS200 pattern 1 (Table 1).

PFGE analysis has been shown to be highly effective for epidemiological studies of a wide variety of bacteria. Recently, this technique has also been used for the molecular typing of Salmonella serovars Enteritidis [11,33] and Typhimurium [27]. Our data confirmed the observation of Olsen et al. [11] that
PFGE was the most discriminatory of the molecular typing methods applied to $S$. Enteritidis. As all $S$. Enteritidis isolates harboured large virulence plasmids, the PFGE fragment patterns were hybridised with a virulence gene probe to determine the possible interference of virulence plasmid bands on the fragment patterns observed. None of the DNA bands visible in ethidium bromide-stained agarose gels could be associated with the faint hybridisation signal obtained with the $s p v \mathrm{~B} / s p v \mathrm{C}$ gene probe. This observation led to the suggestion that large plasmid bands do not account for the restriction fragment length polymorphism detected in the PFGE experiments. Each of the three enzymes used for digestion of the whole-cell DNA of the $S$. Enteritidis isolates resulted in four-to-six different fragment patterns (Table 1). In general, isolates that exhibited the same $X b a \mathrm{I}$ pattern (e.g., pattern 2) could be further differentiated by their SpeI (e.g., patterns 2-5) or Not I patterns (e.g., patterns 2 and 3) and vice versa. Thus, the comparative PFGE analysis with three different suitable restriction endonucleases distinctly increased the discriminatory value of this method. 
Moreover, the use of several enzymes provided a way to circumvent difficulties that might arise from the presence of protection systems in $S$. Enteritidis against cleavage by a particular restriction endonuclease. Protection against cleavage by $N o t \mathrm{I}$ was reported to occur in S. Enteritidis PT16 [11]. As shown in Table 1 , the combination of the results of the three PFGE experiments subdivided the $31 \mathrm{~S}$. Enteritidis isolates into nine genomic groups that corresponded closely to the assignment of the isolates to different phage types. The observation that a PT7 strain was indistinguishable from strains of PT4 by IS200 typing and PFGE analysis confirmed the close genetic relationship between strains of these two phage types. This had been suggested by the observation that a $S$. Enteritidis PT4 strain could be converted into a PT7 strain by loss of lipopolysaccharide [44]. Isolates of PT1 could be subdivided into three genomic groups. This finding accorded with the data of Olsen et al. [11] and confirmed the usefulness of this molecular typing method for discrimination among PT1 strains. Although the $S$. Enteritidis isolates used in this study were isolated from different geographical areas in Northern Germany during a 12-year period, isolates of phage types other than PT1 could not be differentiated further by any of the molecular techniques applied. These observations support the assumption of a clonal relationship of $S$. Enteritidis isolates of certain phage types such as PT4 or PT8. Nevertheless, extended PFGE analyses resulted in a detailed strain characterisation that might be particularly helpful for the characterisation of $S$. Enteritidis isolates that were non-typable by phage typing. These molecular typing methods not only help to follow such non-phagetypable strains in epidemiological studies, they also show the genotypic relationship of these strains to $S$. Enteritidis strains of known phage types (Table 1).

Although these data were obtained from a relatively small number of unrelated $S$. Enteritidis field isolates, this study demonstrated that PFGE analysis might represent a valuable tool for the characterisation of $S$. Enteritidis isolates. Moreover, as the results from PFGE analysis matched closely those from phage typing, PFGE analysis might represent a useful molecular alternative to phage typing in epidemiological studies of $S$. Enteritidis.

The authors thank N. El Solh for providing plasmid pBA2, J. Stanley for plasmid pIZ45, R. Helmuth for plasmid pRQ51, S. Matthes for providing $S$. Enteritidis isolates, Eva Pedersen for phage typing, $\mathrm{H}$. C. Wegener, J. E. Olsen, M. N. Skov and D. J. Brown for helpful discussions and $H$. Meyer and $E$. Nußbeck for excellent technical assistance.

\section{References}

1. Rodrigue DC, Tauxe RV, Rowe B. International increase in Salmonella enteritidis: A new pandemic? Epidemiol Infect 1990; 105: 21-27.

2. Kühn H, Rabsch W, Liesegang A. Gegenwärtige epidemiolo- gische Situation bei der Salmonellose des Menschen in Deutschland. Immun Infekt 1994; 22: 4-9.

3. Anonymous. PHLS-SVS: update on salmonella infection. Public Health Laboratory Service-State Veterinary Service, 1993: 16.

4. Coyle EF, Palmer SR, Ribeiro CD et al. Salmonella enteritidis phage type 4 infection: association with hen's eggs. Lancet 1988; 2: 1295-1297.

5. Humphrey TJ, Mead GC, Rowe B. Poultry meat as a source of human salmonellosis in England and Wales. Epidemiol Infect 1988; 100: 175-184.

6. Millemann Y, Lesage M-C, Chaslus-Dancla E, Lafont J-P. Value of plasmid profiling, ribotyping, and detection of IS200 for tracing avian isolates of Salmonella typhimurium and $S$ enteritidis. J Clin Microbiol 1995; 33: 173-179.

7. Threlfall EJ, Frost JA. The identification, typing and fingerprinting of Salmonella: laboratory aspects and epidemiological applications. J Appl Bacteriol 1990; 68: 5-16.

8. Olsen JE, Brown DJ, Skov MN, Christensen JP. Bacterial typing methods suitable for epidemiological analysis. Applications in investigations of salmonellosis among livestock. Vet $Q 1993 ; 15$ : $125-135$.

9. Helmuth R, Schroeter A. Molecular typing methods for $S$ enteritidis. Int $J$ Food Microbiol 1994; 21: 69-77.

10. Threlfall EJ, Chart $H$. Interrelationships between strains of Salmonella enteritidis. Epidemiol Infect 1993; 111: 1-8.

11. Olsen JE, Skov MN, Threlfall EJ, Brown DJ. Clonal lines of Salmonella enterica serotype Enteritidis documented by IS200-, ribo-, pulsed-field gel electrophoresis and RFLP typing. $J$ Med Microbiol 1994; 40: 15-22.

12. Powell NG, Threlfall EJ, Chart H, Rowe B. Subdivision of Salmonella enteritidis PT4 by pulsed-field gel electrophoresis: potential for epidemiological surveillance. FEMS Microbiol Lett 1994; 119: 193-198.

13. Barry A, Thornsberry C. Susceptibility tests: diffusion test procedures. In: Lennette EH, Balows A, Hausler WJ, Shadomy HJ (eds) Manual of clinical microbiology, 4th edn. American Society for Microbiology, Washington DC, 1985: 978-987.

14. Ward LR, de Sa JDH, Rowe B. A phage-typing scheme for Salmonella enteritidis. Epidemiol Infect 1987; 99: 291-294.

15. Schwarz S, Liebisch B. Use of ribotyping, IS200 typing and plasmid analysis for the identification of Salmonella enterica subsp. enterica serovar Typhimurium vaccine strain Zoosaloral $\mathrm{H}$ and its differentiation from wild type strains of the same serovar. Zentralbl Bakteriol 1994; 281: 442-450.

16. Jordens JZ, Hall LMC. Characterisation of methicillin-resistant Staphylococcus aureus isolates by restriction endonuclease analysis of chromosomal DNA. J Med Microbiol 1988; 27: 117-123.

17. Kado CI, Liu ST. Rapid procedure for detection and isolation of large and small plasmids. $J$ Bacteriol 1981; 145: 1365-1373.

18. Macrina FL, Kopecko DJ, Jones KR, Ayers DJ, McCowen SM. A multiple plasmid-containing Escherichia coli strain: convenient source of size reference plasmid molecules. Plasmid 1978; 1: 417-420.

19. Montenegro MA, Morelli G, Helmuth R. Heteroduplex analysis of Salmonella virulence plasmids and their prevalence in isolates of defined sources. Microb Pathog 1991; 11: 391-397.

20. Olsen JE. An improved method for rapid isolation of plasmid DNA from wild-type Gram-negative bacteria for plasmid restriction profile analysis. Lett Appl Microbiol 1990; 10: 209212.

21. Sambrook J, Fritsch EF, Maniatis T. Molecular cloning: a laboratory manual, 2nd edn. Cold Spring Harbor, NY: Cold Spring Harbor Laboratory, 1989.

22. Iglesias A, Ceglowski $P$, Trautner TA. Plasmid transformation in Bacillus subtilis. Effects of the insertion of Bacillus subtilis rRNA genes into plasmids. Mol Gen Genet 1983; 192: 149-154.

23. Gibert I, Barbé J, Casadesús J. Distribution of insertion sequence IS200 in Salmonella and Shigella. J Gen Microbiol 1990; 136: 2555-2560.

24. Chowdry N, Threlfall EJ, Rowe B, Stanley J. Genotype analysis of faecal and blood isolates of Salmonella dublin from humans in England and Wales. Epidemiol Infect 1993; 110: 217-225.

25. Gulig PA. Virulence plasmids of Salmonella typhimurium and other salmonellae. Microb Pathog 1990; 8: 3-11.

26. Gulig PA, Caldwell AL, Chiodo VA. Identification, genetic analysis and DNA sequence of a $7.8 \mathrm{~kb}$ virulence region of the Salmonella typhimurium virulence plasmid. Mol Microbiol 1992; 6: $1395-1411$.

27. Schwarz S, Liebisch B. Pulsed-field gel electrophoretic identi- 
fication of Salmonella enterica serovar Typhimurium live vaccine strain Zoosaloral H. Lett Appl Microbiol 1994; 19: 469-472.

28. Hunter PR, Gaston MA. Numerical index of the discriminatory ability of typing systems: an application of Simpson's Index of Diversity. J Clin Microbiol 1988; 26: 2465-2466.

29. Stanley J, Baquar N, Threlfall EJ. Genotypes and phylogenetic relationships of Salmonella typhimurium are defined by molecular fingerprinting of IS200 and $16 \mathrm{~S}$ rrn loci. J Gen Microbiol 1993; 139: 1133-1140.

30. Stanley J, Jones CS, Threlfall EJ. Evolutionary lines among Salmonella enteritidis phage types are identified by insertion sequence distribution IS200. FEMS Microbiol Lett 1991; 82: 8390 .

31. Stanley J, Burnens AP, Threlfall EJ, Chowdry N, Goldsworthy M. Genetic relationships among strains of Salmonella enteritidis in a national epidemic in Switzerland. Epidemiol Infect 1992; 108: $213-220$.

32. Stanley J, Goldsworthy M, Threlfall EJ. Molecular phylogenetic typing of pandemic isolates of Salmonella enteritidis. FEMS Microbiol Lett 1992; 90: 153-160.

33. Bautsch W. NotI macrorestriction analysis suggests a clonal relationship of Salmonella enterica, ser. enteritidis phage lysotype 4 strains. Infection 1993; 21: 328-330.

34. Olsen JE, Skov M. Genomic lineage of Salmonella enterica serovar Dublin. Vet Microbiol 1994; 40: 271-282.

35. Torre E, Threlfall EJ, Hampton MD, Ward LR, Gibert I, Rowe B. Characterization of Salmonella virchow phage types by plasmid profile and IS200 distribution. J Appl Bacteriol 1993; 75: $435-440$.

36. Stanley J, Burnens A, Powell N, Chowdry N, Jones C. The insertion sequence IS200 fingerprints chromosomal genotypes and epidemiological relationships in Salmonella heidelberg. $J$ Gen Microbiol 1992; 138: 2329-2336.

37. Stanley J, Chowdry N, Powell N, Threlfall EJ. Chromosomal genotypes (evolutionary lines) of Salmonella berta. FEMS Microbiol Lett 1992; 95: 247-252.

38. Olsen JE, Brown DJ, Baggesen DL, Bisgaard M. Biochemical and molecular characterization of Salmonella enterica serotype Berta, and comparison of methods for typing. Epidemiol Infect 1992; 108: 243-260.

39. Threlfall EJ, Torre W, Ward LR, Dávalos-Pérez A, Rowe B, Gibert I. Insertion sequence IS200 fingerprinting of Salmonella typhi: an assessment of epidemiological applicability. Epidemiol Infect 1994; 112: 253-261.

40. Ezquerra E, Burnens A, Jones C, Stanley J. Genotypic typing and phylogenetic analysis of Salmonella paratyphi $B$ and $S$. java with IS200. J Gen Microbiol 1993; 139: 2409-2414.

41. Martinetti G, Altwegg M. rRNA gene restriction patterns and plasmid analysis as a tool for typing Salmonella enteritidis. Res Microbiol 1990; 141: 1151-1162.

42. Helmuth R, Stephan R, Bunge C, Hoog B, Steinbeck A, Bulling E. Epidemiology of virulence-associated plasmids and outer membrane protein patterns with seven common Salmonella serotypes. Infect Immun 1985; 48: 175-182.

43. Brown DJ, Threlfall EJ, Hampton MD, Rowe B. Molecular characterization of plasmids in Salmonella enteritidis phage types. Epidemiol Infect 1993; 110: 209-216.

44. Chart H, Rowe B, Threlfall EJ, Ward LR. Conversion of Salmonella enteritidis phage type 4 to phage type 7 involves loss of lipopolysaccharide with concomitant loss of virulence. FEMS Microbiol Lett 1989; 60: 37-40. 